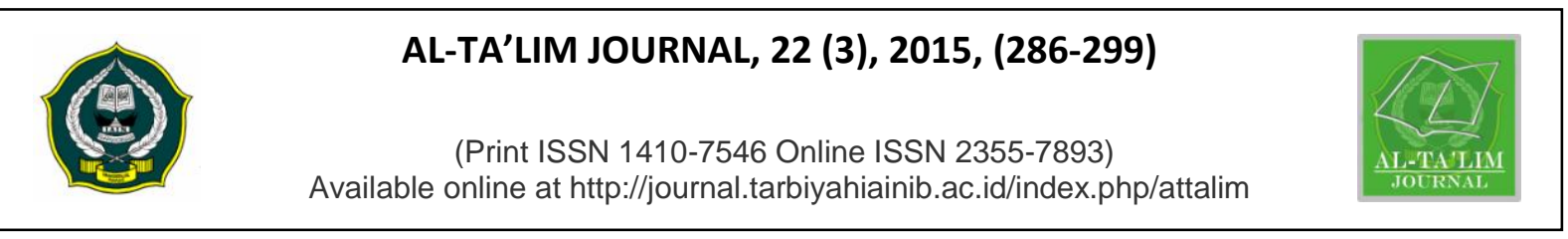

\title{
Improving Students' Activities through the Implementation of Mind Map Script Type (SM2) at SMAN 1 Pulau Punjung
}

\author{
Filmawati \\ Senior High School 1 Pulau Punjung Dharmasraya, West Sumatra, Indonesia \\ E-mail: filmawati21@gmail.com
}

Received: 11th August 2015; Revised: 18th September 2015; Accepted: 24th Oktober 2015

\begin{abstract}
This research is motivated from the deficiency of student's activity in the learning process. The outcome of religious learning process is still low. It shows under 75. By applying cooperative learning model Mind Map Script types, it is expected to be able to enhance students' motivation through working group learning. This study used a qualitative approach to obtain data and analysis through reflective studies, participatory and collaborative. Mind Map Script is applied to increase learning activity and progress. This study was conducted in SMAN 1 Pulau Punjung with 2 cycles from the observation. Student activities increase from $54 \%$ to $75 \%$ in the second cycle. Meanwhile, students' daily test showed an increasing from an average of 65 to 73 in first cycle, and 79 in second cycles. From the first and second cycle of this Classroom Action Research can be concluded that cooperative learning model Mind Map Script types enable to increase students' activity and learning progress especially in Islamic education studies of grade X student of SMAN 1 PULAU PUNJUNG DHARMASRAYA District.
\end{abstract}

Key word: activity and learning progress, cooperative model mind map script type (SM2)

How to Cite: Filmawati, F. (2015). Improving Students' Activities through the Implementation of Mind Map Script Type (SM2) at SMAN 1 Pulau Punjung. Al-Ta Lim, 22(3). doi:http://dx.doi.org/10.15548/jt.v22i3.150

Permalink/DOI: http://dx.doi.org/10.15548/it.v22i3.150

\section{INTRODUCTION}

Islamic Education Teachers (GPAI) has a strategic contribution in developing students' potency in learning of Islam. Teachers are also key figures in instilling noble values of the Islamic religion in terms of character and attitude formation and behavior of learners through a variety of developed learning models. The increasing of students' activity in the learning process generates an effective learning progress. It is believed because, (1) the involvement of the students in preparing and planning the learning process, (2) the intellectual engagement of student's emotional through their encouragement and enthusiasm, (3) Creative participation of students in learning process presented.

The writer has tried to enliven learning atmosphere by doing discussions and question session, including games, role playing and even activities of small group by using a variety of media, including media-based ICT. However, there are some classes affected and they learn with fun learning atmosphere, but it lasts minutes, Learning activities and student's progress are still low, it does not reach the minimum completeness 
criteria (KKM). Class X.5 of 28 students, 20 students or $79 \%$ of the learning progress is less than 75 as its minimum

Another problem I have found that students are reluctant to cooperate; smart students disincline to team up with peers. During the discussion, only one or two student work effectively. Students have fear and feel embarrassed to talk and to ask either to the teacher or a friend.

Student's opportunity to express their ideas is restricted, it is provided to the smart student only. This situation leads student to be passive and student only act as recipient. Students are not empowered; active learning method does not appear. Consequently most students' potentials are embedded.

\section{Learning Activity}

Learning activities is the involvement of students in the form of attitudes, thoughts, attentions, and activities in learning activities to support the success of the learning process and to obtain the benefit from these activities. Kemp argue (1995: 25) to explain that the learning strategy is a learning activity that must be done by teachers and students in order to reach the effectively and efficiently learning objectives

\section{Learning Progress}

Learning outcomes is the realization and application of learning activity done teachers and students. Teacher learning outcomes can be seen through the evaluation, while the students' is known from the end of the learning process. According to Sudjana (2001) learning outcomes are a result of the learning process by using a measurement device, in the planned test form, written test, an oral test and the works test.

\section{Learning Cooperative Model Mind Map Script types (SM2)}

Cooperative learning model is one of learning models that supports contextual learning. Cooperative teaching system can be defined as a system of work / structured study group. Cooperative learning is a teaching and learning strategy that emphasizes the attitude or behavior in work or help among the structured regular cooperation within the group, which consists of two or more people. Cooperative learning is a form of learning based on constructivist ideology.

Script Cooperative Model according to Dansereau (1985) is pair work learning method and where student verbally summarize portions of the material being studied. The steps of script cooperative method are as follow, (1). The teacher divides the students into pairs, (2). Teacher gives a topic / material for each student to read and write summaries, (3). Teachers and students determine who first act as presenter and audience, (4). Speaker read out the summary comprehensively, by incorporating the main ideas in summary, (5). Switch roles, (6). Teachers' conclusion. (7) Closing.

According to Buzan center, Mind Map is an affective chart technique providing a universal key to expose whole potential of the human brain so that it can use all the capabilities that exist on both sides of the brain such as words, pictures, numbers, logic, rhythm, and color in a unique way (Johan Yoga, 2006)

Some important points of mind map that need to notice: 1 . Mind Map is a way of thinking by using a whole part of the right brain and the left brain to see things from different viewpoint to stimulate new creativity. 2. Main map is the relevance of PAI learning method as part of an unconventional method because the mind map is a new formula and still not commonly used in the learning of Islamic Education 


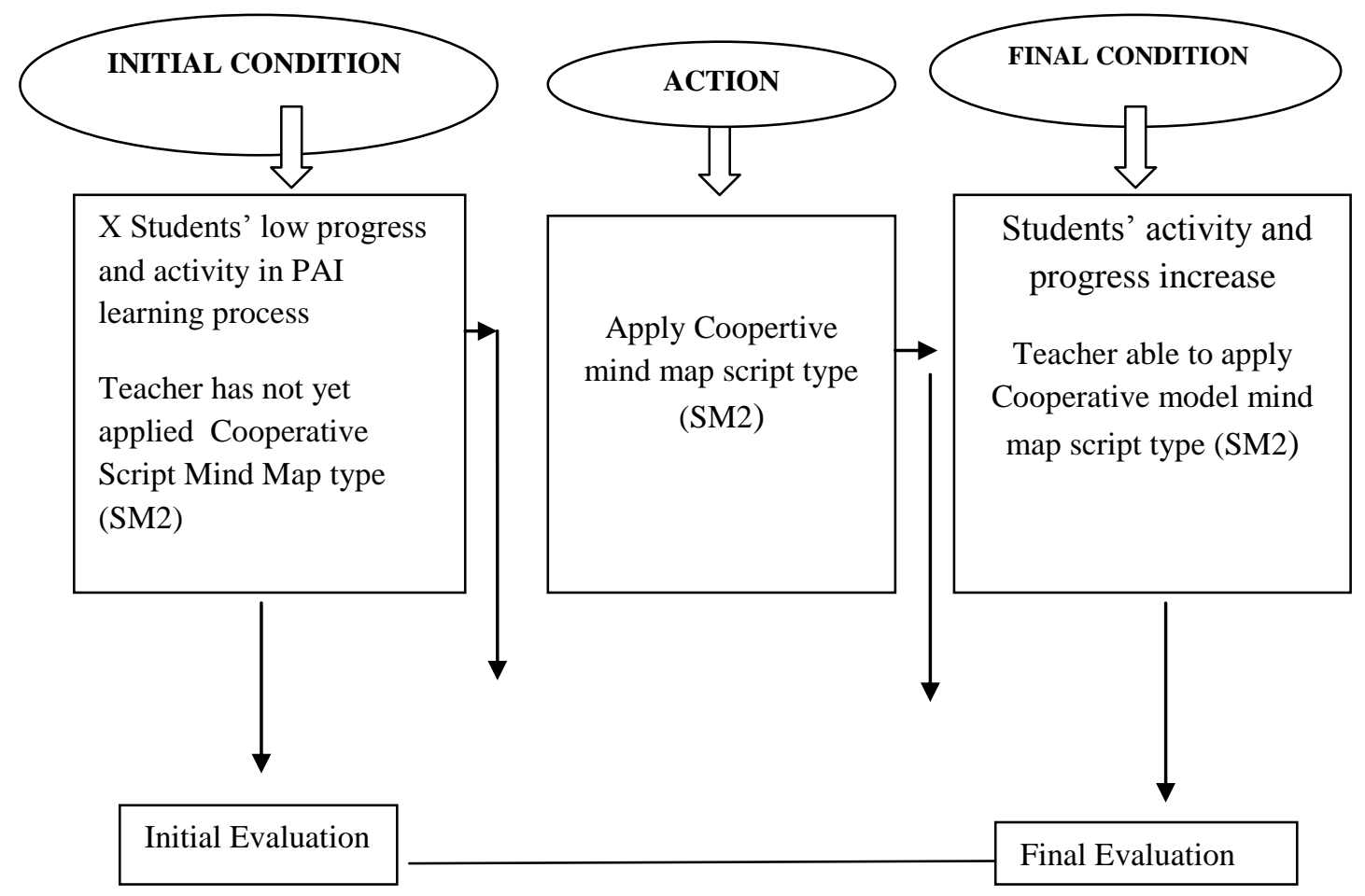

Problem Solving Discussion Application of Cooperative Type SM2

Evaluation of the Effect

Figure 1: Conceptual Framework

\section{METHOD}

The kind of This research is a Classroom Action Research which is reflective action to improve the learning process. Action research is a form of scientific activities carried out by the teacher in the class itself by designing, implementing, observing and reflecting action through several cycles collaboratively and participatory intending to improve and enhance the quality of the learning process in the class. (Kunandar, 2010: 46 ).

There sources of research data are students, teacher, collaborators and colleagues, the analysis used in accordance with the method and type of data collected. Analysis of data using analysis:

1. Qualitative Descriptive, which analyzes based on the observation and reflection of meeting.
2. Comparative Descriptive, it compares the value of the initial conditions test with the value of the test after the first and second cycle. The completeness of student learning outcomes can be viewed individually and classical. A student can be categorized into complete when the learning achievement above minimum completeness criteria $(\mathrm{KKM}=75)$.

Data were analyzed using descriptive analysis techniques that was a description explaining the answers given in the questionnaire respondents, the data obtained through interviews and literature used as supporting data in order to strengthen and deepen the results obtained from the questionnaire. 


\section{Student Activity}

Student's learning activities Data gained from the observation sheet is analyzed by determining the percentage of each activity observed. The percentage of students' learning activities using the formula (Sujana: 2001: 109) as follow:

The percentage activity $=$ number of active students x $100 \%$

Number of student

\section{Students' learning progress}

The progress obtained from final cycle tests is processed by calculating the average. Siswanto (2005: 45) states that the average calculation using the formula

$$
\begin{aligned}
& \text { Average }(X)=\frac{\sum X}{n} \\
& X X=\text { the avare of learning }
\end{aligned}
$$

progress$$
\mathrm{X}_{1}=\text { the average of each }
$$

student

$$
N=\text { number of student }
$$

The first cycle in this CAR consists of planning, implementation, observation, evaluation and reflection as follows:

\section{Planning}
a. Research team analyzes curriculum
b. Preparing lesson plan
c. Setting up the media and tool needed, such as card and script
d. Provide student worksheet
e. Preparing instruments used in CAR's cycle
f. Setting up observation sheets
g. Develop an evaluation tool

\section{Implementation}

a. Teachers coordinate the class according to a scenario that had been developed with the colleague's supervision to observe the desired indicators, among others:

1) provide interview card in pairs

2) guide student in using interview card

3) divide student into groups according to the card

4) teacher guides the group discussion
5) the result of discussion write into mind mapping

6) group presents the topic discussed

7) teacher assign a quiz or question

8) students are given opportunity to provide feedback

9) determining the conclusion

10) observation

b. Assessment conducted in the end of the learning process.

3. Observation

a. Situation of learning activities

b. individually student activity

c. student ability in group discussion

4. Evaluation (Evaluating)

It is done by collecting data through observation sheets and tests given at the end of the lesson, so that the data obtained from students score presented in a list of score

5. Reflection

CAR is successful if it meets several conditions as follows:

a. Most (75\% of students) active in learning

b. Most (70\% of students) active in group discussions.

c. The student finishes the task on time

The second cycle was also composed of planning, implementation, observation, evaluation and reflection

1. Planning

a. Meeting with colleagues to discuss the implementation of the first cycle

b. Develop learning scenarios

b. Provide the necessary media tools such as colorful cards containing the name of the group

c. Setting up the observation sheet (teachers and students activities)

e. Setting up student work sheet

2. Implementation

a. Teachers coordinate the class according to a scenario developed 
with the assistance of colleagues to observe the indicator

b. Assessment conducted in the end of the learning process

3. Observation

Observations conducted with colleagues in accordance with an agreed format (format attached)

4. Evaluation

It's done by collecting data through observation sheets and tests given at the end of the learning process.

5. Reflection

Based on the actions taken in the first cycle found weaknesses, and it is improved on the second cycle, so the students' activity and progress in learning Islamic education through cooperative model mind map script type are increased.

\section{RESEARCH FINDINGS DISCUSSION}

AND

\section{Cycle 1}

Cycle 1 took place from September 24 to October 8, 2013, on the subject of faith in Allah through His attributes in Beautiful Names in 3 meetings, with the following steps:

\section{Step 1: Planning}

Based on initial test results (first daily test), planned the following things: first, to analyze the curriculum to determine the standard of competence and competence that will be presented to students with a Cooperative model of Mind Map script type (SM2).

Second, prepare lesson plan of Cooperative model of Mind Map Script types (SM2). In this study plan, researchers described the steps to increase students' activity and progress. Third, teacher prepared teaching materials in the form of mind map based on ICT and card media containing discourse or subject material in two colors for the application of the script method. Fourth, preparing the instruments used in a cycle of
CAR, such as the sheets for students and teachers to observe students' and teachers' learning activities individually and in group discussions during learning process. Fifth, teacher prepared Students worksheet in discussion. Sixth, teacher compiled of learning evaluation device in the form of test and assessment groups' presentations.

\section{Step 2: Implementation}

In the first cycle, PBM is applied in 3 meetings; each meeting is 90 minutes ( $2 \times 45)$.

\section{1). First meeting}

At the first meeting of the first cycle, the teacher started the meeting with greetings and started learning by saying basmalah and prayer (teacher / Chair man instructed the class with Arabic and reported student attendance). Teacher explained the standard of competence, basic competence, indicators of achievement and learning objectives.

Teachers presented the range of material and brief description of steps implemented and motivated students to always believe in Allah SWT (by asking questions). Furthermore, teacher lead students to arrange the seating in opposite pairs and provide discourse / card containing sub material to all students (each pair got the same card).

Students read and understand the material alternately. Then, every student represented the contents and the peer corrected it in turn. Teachers guided students to share the contents of discourse or student card.

Teachers concluded the material by showing the slide of Faith in Allah by Buzan's iMind Map V.4.1 via LCD. They motivated the learners who are less active or have not participated. Then, the teacher gave final quiz (teachers using alternative media such as: Word Square, Scramble, Guess Words or Rubbic's cube). Finally the teacher gave the reflection process and learning result by providing reinforcement. They appreciated students' learning progress either individually or in groups. Teacher planed following 
activities (remedial or enrichment) and pictured the lesson plan for the next meeting. Teachers closed / ended the lesson by asking students to read hamdalah / prayer together

\section{2) Second Meeting}

In the second meeting of first cycle, the teacher started the meeting and learning with greetings and read basmalah and prayer (teacher / Chair man instructed the class with Arabic and chairman reported student attendance).Next teacher explained standard competence, basic competence, indicators and the achievement of learning objectives.

Teachers explained the range of material and brief description of learning activity by showing the video of 99 Asmaul Husna (beautiful names of Allah)

Furthermore, teachers lead students to arrange the seating into six groups; each group consists of 5 people with the same topic based on the card number. Furthermore, teachers lead students work and discussions in their groups and teacher provided the assistance if they need. After the teacher and students doing the briefing and teacher concluded the lesson by showing a slide of Almaul Husna by Buzan's Mind Map V.4.1 via LCD. Teachers confirmed the results of exploration and elaboration of learners through a slide show with a mind map program and provided motivation to learners.

Finally the teacher gave final quiz (teachers used a variety of alternative media such as: Word Square, puzzles, Scramble, Guess Words or Rubbic's cube). Teachers provided a reflection of learning outcomes process by providing reinforcement and reward to the students, either individually or in groups, teacher planed following activities (remedial or enrichment). Teachers closed / ended the lesson by asking students to read hamdalah / prayer together

3) Third meeting

At the third meeting of the first cycle, the teacher started the meeting and learning by greetings and says basmalah and prayer (teacher / Chair man instructed the class with Arabic and chairman reported student attendance). Teacher explained standard competence, basic competence, indicators and the achievement of learning objectives. Teachers presented the range of material and brief description of steps activity showed by the film of the majesty of Almighty God. Teachers lead students to arrange the seating in groups of six, each consists of 5 people with the same topic based on the six color card.

After the teacher and students do debriefing, teacher concluded the lesson by showing a slide of 10 Asmaul Husna with Buzan's iMind Map V.4.1 program via LCD. Teacher confirmed the results of exploration and elaboration of learners through a slide show with a mind map program and provided motivation to learners. Finally the teacher gave final quiz (teachers use a variety of alternative media such as: Word Square, puzzle, Scramble, Guess Words or Rubbic's cube). Teacher provided a reflection process and learning outcomes by providing reinforcement and student's reward of learning outcomes either individually or in groups, teacher plans following activities (remedial or enrichment).

\section{Step 3: Observation}

1). Observation of Student Learning
Activity
a) Individual Activity While learning
process

Table 2: Observations Distribution of Learning activities in Cycle I

\begin{tabular}{l|l|l|l|l|l|l|l|c}
\hline \multirow{2}{*}{ No } & ACTIVITY OBSERVED & \multicolumn{2}{|l|}{ MET 1} & \multicolumn{2}{l|}{ MET 2} & \multicolumn{2}{l}{ MET 3 } & \multirow{2}{*}{ EVRAGE } \\
\cline { 3 - 8 } & & $F$ & $\%$ & $F$ & $\%$ & $F$ & $\%$ & \\
\hline 1 & Students read the reference (topic) & 20 & 74 & 24 & 89 & 24 & 89 & $\mathbf{8 4}$ \\
\hline 2 & Students heed the lesson & 20 & 74 & 24 & 89 & 25 & 93 & $\mathbf{8 5}$ \\
\hline 3 & Students give the ideas and question & 3 & 11 & 5 & 19 & 10 & 37 & $\mathbf{2 2}$ \\
\hline 4 & Students answer the question & 5 & 19 & 7 & 26 & 10 & 37 & $\mathbf{2 7}$ \\
\hline
\end{tabular}




\begin{tabular}{l|l|l|l|l|l|l|l|c}
\hline 5 & Students report the final of learning & 10 & 37 & 12 & 44 & 10 & 37 & $\mathbf{3 9}$ \\
\hline 6 & $\begin{array}{l}\text { Students listen to the descriptions, } \\
\text { conversation, discussion. }\end{array}$ & 20 & 74 & 18 & 67 & 20 & 74 & $\mathbf{7 2}$ \\
\hline 7 & $\begin{array}{l}\text { Students take notes and write a } \\
\text { conclusion. }\end{array}$ & 10 & 37 & 15 & 56 & 20 & 74 & $\mathbf{5 6}$ \\
\hline 8 & $\begin{array}{l}\text { Student enthusiasm and passion in } \\
\text { learning }\end{array}$ & 10 & 37 & 12 & 44 & 16 & 59 & $\mathbf{4 7}$ \\
\hline AVERAGE & & 45 & & 54 & & 63 & $\mathbf{5 4}$ \\
\hline
\end{tabular}

Students who pay attention are 20 students $(74 \%)$, the second meeting is 24 students $(89 \%)$ and third meeting is 25 students (93\%). Generally, a lot of students pay attention to the lesson. There is an enhancement in each meeting.

Students giving ideas and questions in first meeting are 3 students $(11 \%)$. In second meeting is five students (19). In third meeting is 10 students $(37 \%)$. It means that the activity is low; meanwhile, students answering questions at first meeting are five students (19\%). In second meeting is 7 students (26) and in the third meeting is 10 $(37 \%)$ it means that the students' activity is still low.

Student reporting the work or presentation at the first meeting is 3 students ( $37 \%)$, in the second meeting is 12 students
(44) and in the third meeting is $10(37 \%)$. It means that the activity of student is low.

Student listening to the lesson on first meeting is 20 students (74\%), in the second meeting is 18 (67) and the third meeting is 20 $(74 \%)$. It means that the activity of student is increase.

Student taking note and writing conclusion at the first meeting is 10 students (37\%), in the second meetings is 15 (56) and the third meeting is 20 students $(74 \%)$. It means that the student activity is increased

Student enthusiasm and passion in learning at the first meeting is 10 students (37\%), in the second meeting is 12 (44) and the third meeting is 16 students (59\%) it means that student activity is categorized into high.

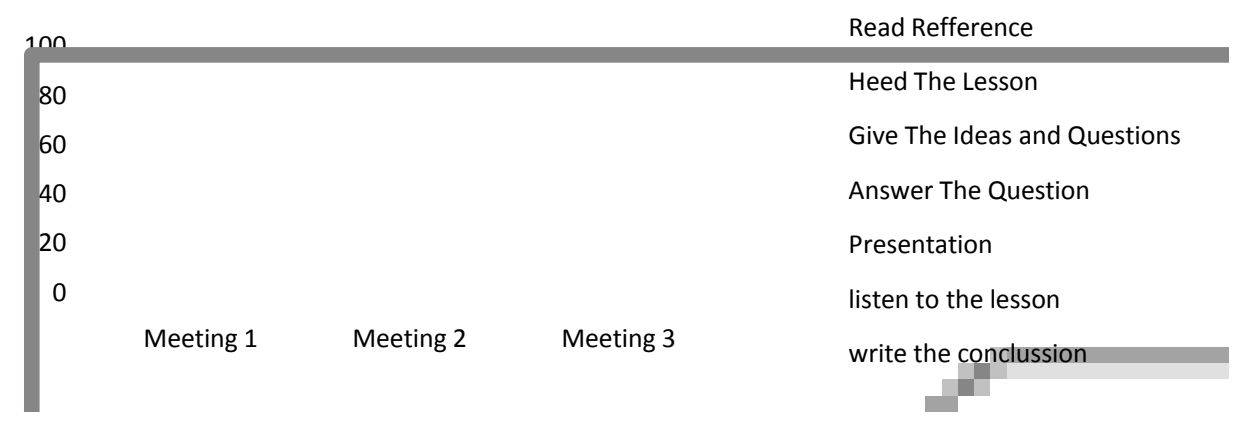

Figure1: Observations Distribution of learning activities in Cycle I 
b). Students' Group Discussion Activity in

Table 3: Observation Distribution of Group Discussion Activity in Cycle 1

\begin{tabular}{|l|l|l|l|l|l|l|l|}
\hline \multirow{2}{*}{ NO } & GROUP & \multicolumn{2}{|l|}{ ACTIVITY OBSERVED } & TOTAL & $\%$ \\
\cline { 3 - 7 } & & Team Work & Enthusiasm & Dicipline & Communication & SCORE & \\
\hline 1 & Thankfull & 2 & 3 & 2 & 2 & 9 & 56 \\
\hline 2 & Patient & 3 & 3 & 4 & 4 & 14 & 88 \\
\hline 3 & Confident & 4 & 3 & 2 & 3 & 12 & 75 \\
\hline 4 & Persistent & 3 & 3 & 2 & 2 & 10 & 63 \\
\hline 5 & Initiative & 3 & 3 & 2 & 2 & 10 & 63 \\
\hline 6 & Gracious & 2 & 2 & 2 & 2 & 8 & 50 \\
\hline \multicolumn{2}{|l|}{ TOTAL } & 17 & 17 & 14 & 15 & 63 & 66 \\
\hline \multicolumn{2}{|l|}{ AVERAGE } & 71 & 71 & 58 & 63 & 66 & \\
\hline
\end{tabular}

Based on the table above, the highest score of students' activity in group

discussions is 88 and the lowest is 50 with the average $66 \%$. It needs to be increased.

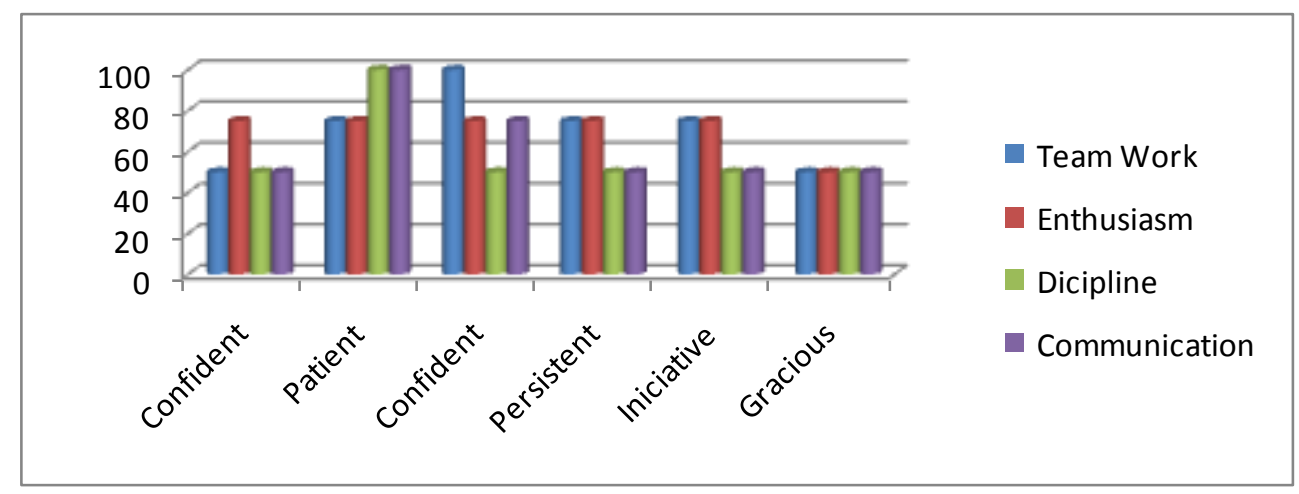

Figure 2: Observation Distribution of Group Discussion Activity cycle 1

\section{2). Teacher Activity Observation}

Teachers' activity observed at the first meeting is how teachers appreciate, explain the material, explain the methods and models of learning, manage class, divide groups, use the media, manage discussions, group counseling, provide questions and quizzes, individuals and groups rewards, evaluate and determine the value of individuals and groups, conclude and close the lesson.

Table 4: Recapitulation of Teachers' Activity in Learning Cycle I

\begin{tabular}{l|l|l|l|l}
\hline cycle & Score obtained & Ideal Score & $\%$ & Criteria \\
\hline I & 45 & 56 & 80 & High \\
\hline
\end{tabular}

Based on the table above, the teachers' activities obtain a score of $45(80 \%)$ which means that the activity of teacher needs to be improved.

\section{3). Student Outcomes Assessment}

The uncompleted result of students learning outcomes through Daily test and presentation in first cycle shows in the table below: 
Table 5: Recapitulation of Students' pre- and cycle 1

\begin{tabular}{|c|c|c|c|c|c|c|c|c|}
\hline \multirow[t]{3}{*}{ cycle } & \multirow[t]{3}{*}{ Grade } & \multicolumn{2}{|l|}{ Student } & \multirow[t]{3}{*}{ average } & \multicolumn{4}{|c|}{ Completeness } \\
\hline & & \multirow{2}{*}{ number } & \multirow[t]{2}{*}{ present } & & \multicolumn{2}{|c|}{ Complete } & \multicolumn{2}{|c|}{ Uncomple } \\
\hline & & & & & total & $\%$ & total & $\%$ \\
\hline Pree-cycle & $X .5$ & 28 & 28 & 65 & 8 & 29 & 20 & 79 \\
\hline Cycle 1 & $X .5$ & 27 & 27 & 73 & 16 & 59 & 11 & 41 \\
\hline
\end{tabular}

Based on the table above, it shows that an increasing in students' learning outcomes in pre-cycle before applying the model of Cooperative Mind map script type (SM2). The level of students completeness only 8 (29\%) with the average of 65 , whereas in the first cycle after applying of Cooperative model Mind map script type (SM2), student progress is increased to $16(59 \%)$, which reached the Maximum of completeness average criteria of 73 .

\section{Step 4: Reflection}

If the students unable to reach the maximum, that means the indicator need to be evaluated. The evaluation result of the first cycle only reached an average of 73 . There are groups that have not been able to complete the task at the specified time. This is because members of the group are less serious and unable to perform the result of discussion. In fact, teachers have created a relevant learning environment. This data obtained from the data observation that reaches $80 \%$.

To maintain the success that has been achieved in the first cycle, the second cycle can be developed by these steps:

a. Motivate the group to be more active in learning

b. More intensive in guiding groups facing difficulty

c. Give recognition and reward to students.

\section{Cycle II}

\section{Step 1: Planning}

Based on the reflection, the effort is necessary to improve the activity and student learning outcomes as it is still in the medium category. So responded by these steps: first, analyze the curriculum to determine the standard of competence and basic competence to be delivered to the students with Cooperative models Mind Map Script Type (SM2). Familiarize Husnuzzhan (positive thinking) behavior in everyday life. Second, to prepare the lesson plan. In this Lesson Plan, researchers describe any measures to be implemented in increasing students' outcomes. Third, to prepare teaching materials in the form of mind map based on ICT and media cards containing discourse or subject in two colors for applying the method script. Fourth, to prepare the instrument used in the cycle of CAR such as sheets for students and teachers to observe teacher and student activities. Fifth, prepare students' work sheet in the discussion and sixth, develop evaluation learning guide such as question, and discussion.

\section{Step 2: Implementation}

Named the group by Gratitude, Patience, Confidence, Persistence, initiative and gracious. Furthermore, teachers lead students to work and do discussions. Teachers allow students to initiate activities and discuss the subject by combining the entire sub materials. Teachers supervise and guided the students if the had a trouble. Students write the results of the discussion into Mind mapping on paper. So the teacher and students discussed the finding of each group, then the teacher concluded the materials with a slide show of 10 Asmaul husna with Buzan's program iMind Map V.4.1 via LCD. The teacher confirmed the results of 
exploration and elaboration of learners through a slide show with a mind map program and provided motivation to learners who are less active or have not participated.

Finally the teacher gave final quiz (teachers used a variety of alternative media such as: Word Square, puzzle, Scramble, Guess Words or Rubric's cube). Teachers provided a process of reflection and learning outcomes by providing reinforcement and students' reward either individually or in groups., teacher plan the following activities (remedial or enrichment) .teacher ended the class by asking students to read hamdalah/ prayer together.

\section{3). Third meetings}

At the third meeting in the first cycle, the teacher started the meeting with greetings and read basmalah. (Teacher or Chairman instructed the class with Arabic and chairman reported student attendance) .Next teacher explains standard competence, basic competence, indicators and the achievement of learning objectives.

Teachers delivered the range of material and brief description to be implemented and show the movie on "Fighting learner". Furthermore, the teacher lead students to arrange the seating in groups of 6 . Each group consist of 5 people who have the same topic and discourse based on the six color card. Each name is Gratitude, Patience, Confidence, Persistence, initiative and gracious, Furthermore, teachers lead students work and do discussions in their respective groups and ask learners to ask if there are not yet clear.

Teachers allowed students to initiate activities and discussed the subject by combining the entire sub materials. Teachers supervised and guided the students if the had a trouble. Students write the results of the discussion into Mind mapping on paper. So the teacher and students discussed the finding of each group, after discussion, the member of the groups revised the group work. Finally the teacher gave final quiz (teachers use a variety of alternative media such as: Word Square, Scramble, Guess Words or Rubbic's cube). Teachers provided a process of reflection and learning outcomes by providing reinforcement and students' reward of learning outcomes either individually or in groups. Teacher planed following activities (remedial or enrichment). Teachers ended the lesson by asking students to read hamdalah / prayer together

\section{Step 3: Observations}

1). Observation of the Student Activity

a) Individual activity during the learning process

Table 6: Distribution of Observation Learning Activity in Second Cycle

\begin{tabular}{l|l|l|l|l|l|l|l|l}
\hline \multirow{2}{*}{ No } & Students' Activity Observed & \multicolumn{2}{l}{ met 1} & \multicolumn{2}{l|}{ met 2} & \multicolumn{2}{l}{ met 2 Average } \\
\cline { 3 - 8 } & & $F$ & $\%$ & $F$ & $\%$ & $F$ & $\%$ & \\
\hline 1 & Read The Topic & 25 & 93 & 25 & 93 & 27 & 100 & $\mathbf{9 5}$ \\
\hline 2 & Heed The Lesson & 25 & 93 & 25 & 93 & 27 & 100 & $\mathbf{9 5}$ \\
\hline 3 & Give Ideas and question & 6 & 22 & 8 & 30 & 11 & 41 & $\mathbf{3 1}$ \\
\hline 4 & Answer the question & 12 & 44 & 15 & 56 & 17 & 63 & $\mathbf{5 4}$ \\
\hline 5 & Report the Presentation Finding & 15 & 56 & 20 & 74 & 20 & 74 & $\mathbf{6 8}$ \\
\hline 6 & $\begin{array}{l}\text { Listen to the expanation, } \\
\text { discussion. }\end{array}$ & 25 & 93 & 25 & 93 & 27 & 100 & $\mathbf{9 5}$ \\
\hline 7 & Write the conclusion & 21 & 78 & 20 & 74 & 25 & 93 & $\mathbf{8 2}$ \\
\hline 8 & Motivated in learning & 18 & 68 & 21 & 78 & 25 & 93 & $\mathbf{8 0}$ \\
\hline Average & & 68 & & 74 & & 83 & $\mathbf{7 5}$ \\
\hline
\end{tabular}

Based on the table above, students who read a reference in the first meeting is 25 students (93\%), the second is $25(93 \%)$ and the third meeting is $27(100 \%)$ and an average 
is $95 \%$. It means that there is a significant increasing of the student in reading the reference.

Students who pay attention in learning process is $25(93 \%)$, the second meeting is 25 students $(93 \%)$ and the third meeting is 27 $(100 \%)$. It means there are a lot of students have serious attention while learning process, there is significant increasing especially in the third meeting.

Students who give ideas and question in the first meeting is 6 students $(22 \%)$, in the second meeting is 8 persons $(30 \%)$ and the third meeting is 11 students (41\%), although there was an increasing from the first cycle but it is categorized low. While the students answering questions at the first meeting is 12 students (44\%), the second meetings is 15 (56) and the third meeting is $17(63 \%)$. It is categorized into high and it is also increase from the first cycle.
Students reporting the presentation finding at the first meeting is 15 students (56\%). 20 (74) students reported at the second meeting and the third meeting is $20(74 \%)$ students. It can be concluded that student's activities is categorized into high level. Student listening to a lesson on first meeting is 25 students (93\%), at the second meeting 25 student (93). The last meeting was 27 students (100\%). It means that all students listened to the lesson explanation. While student recording and writing conclusion at the first meeting was 21 students $(78 \%)$, next meeting was 20 students (74) then, 25 students $(93 \%)$. it means, there are a lot of student have high level of learning activity.

Student enthusiasm and passion in learning at the first meeting was about 18 students (68\%), second meeting was 21 persons (78)and last meeting was 25 student (93\%) it's categorized to high level.

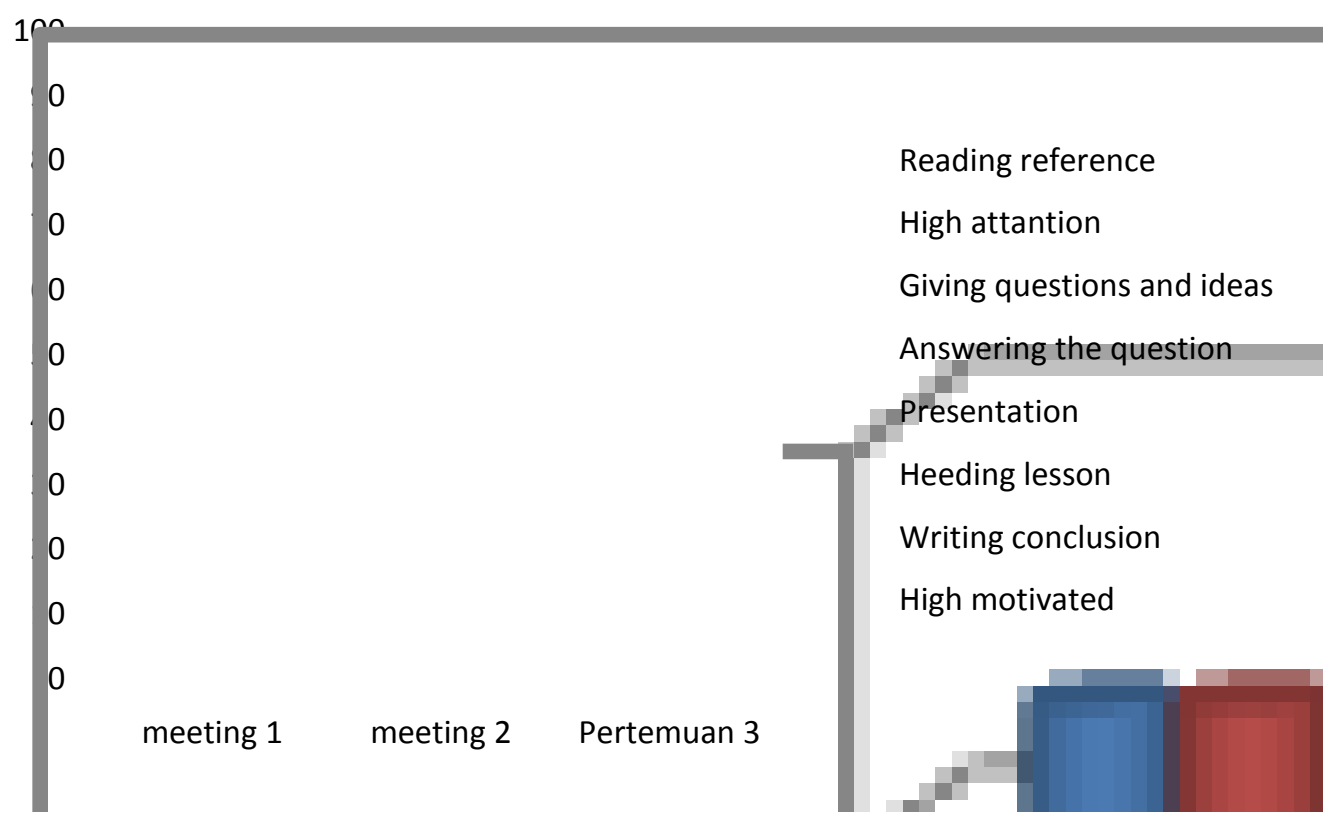

Figure 3: Distribution of Learning activity Observation in Cycle II 
b). Student activity $\mathrm{n}$ group discussion

Table 7: Distribution of Group Discussion Activity Observed in Cycle II

\begin{tabular}{|l|l|l|l|l|l|l|l|}
\hline \multirow{2}{*}{ NO } & \multirow{2}{*}{ Group } & \multicolumn{5}{|c|}{ Activity observed } & \multirow{2}{*}{$\begin{array}{c}\text { Total } \\
\text { Score }\end{array}$} \\
\cline { 3 - 8 } & & Group Work & Enthusiasm & Discipline & communication & & \\
\hline 1 & Thankful & 2 & 3 & 3 & 3 & 11 & 69 \\
\hline 2 & Patient & 4 & 4 & 3 & 4 & 15 & 94 \\
\hline 3 & Confident & 4 & 4 & 4 & 3 & 15 & 94 \\
\hline 4 & Persistent & 3 & 3 & 3 & 3 & 12 & 75 \\
\hline 5 & Initiative & 3 & 3 & 2 & 3 & 11 & 69 \\
\hline 6 & Gracious & 3 & 3 & 2 & 2 & 10 & 63 \\
\hline total & 19 & 20 & 17 & 18 & 74 & 77 \\
\hline average & 79 & 83 & 71 & 75 & 77 & \\
\hline
\end{tabular}

The table above shows the highest 94 and the lowest 63 of students' activity level in group discussions with the average of $77 \%$. It is increased.

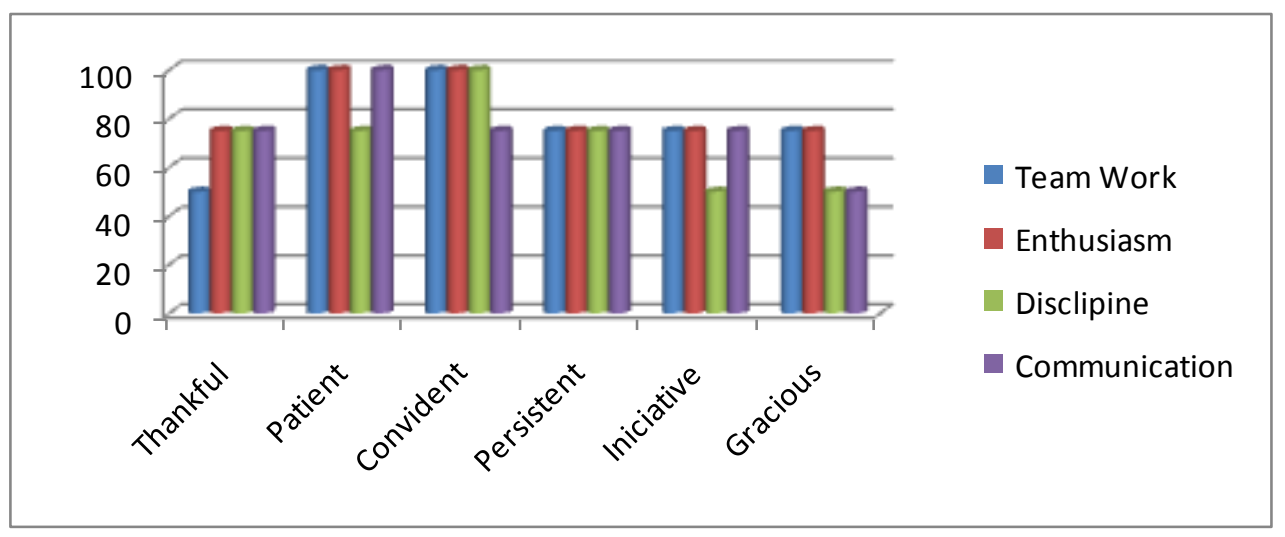

Figure 4: Distribution of Discussion Activity Observed in Cycle I

\section{2). Teacher Activity Observation}

Teacher Activity observed at the meeting of the second cycle is how teachers appreciate, explain the material, explain the methods and models of learning, share groups, master classes, use the media, manage discussions, group counseling, provide questions and quizzes, individuals and groups member rewards, evaluate and determine the value of individuals and groups, conclude and end the lesson.

Table 8: Recapitulation of Teacher Learning Cycle II

\begin{tabular}{l|l|l|l|l}
\hline Cycle & Score Obtained & Ideal Score & $\%$ & Criteria \\
\hline II & 50 & 56 & 89 & High \\
\hline
\end{tabular}


Based on the table above, Teachers' activity reached score of 50 (89\%) which means that the activity of the teacher in the high category.

\section{3). Student Learning Progress}

Student Learning Progress through Daily Test and Presentation which is not meet the minimum of completeness (75) at the pre-cycle and cycle I, II shows in the table 9.

Table 9: Recapitulation of Students' Learning Progress (Daily Test ) Pre-Cycle and Cycle I, II

\begin{tabular}{|c|c|c|c|c|c|c|c|c|}
\hline \multirow[t]{3}{*}{ Cycle } & \multirow[t]{3}{*}{ Class } & \multicolumn{2}{|l|}{ Student } & \multirow[t]{3}{*}{ Average } & \multicolumn{4}{|c|}{ Completeness } \\
\hline & & \multirow[t]{2}{*}{ Number } & \multirow[t]{2}{*}{ Present } & & \multicolumn{2}{|c|}{ Complete } & \multicolumn{2}{|c|}{ Uncomplete } \\
\hline & & & & & Total & $\%$ & Total & $\%$ \\
\hline $\begin{array}{l}\text { Pree- } \\
\text { Cycle }\end{array}$ & $X .5$ & 28 & 28 & 65 & 8 & 29 & 20 & 79 \\
\hline Cycle 1 & $X .5$ & 27 & 27 & 73 & 16 & 59 & 11 & 41 \\
\hline Cycle 2 & $X .5$ & 27 & 27 & 79 & 23 & 85 & 4 & 15 \\
\hline
\end{tabular}

The table above shows that an increasing in student learning outcomes in the first cycle after applying the SM2. Students' level of completeness is only $16(59 \%)$ with the average of 73 , while it is increased in the second cycle to 23 students $(85 \%)$, which reached the average completeness of 79 .

\section{Step 4: Reflection}

Based on teacher field notes, peers observations and Learning Progress Research present that the students' activity and progress are increased.

The success obtained during this second cycle is the students' activity in Learning Process has led to cooperative learning. Students have been able to build team work in the group to understand the assignment of teachers. Students have initiated to present their work well. Data shows the students activity increases from $54 \%$ in the first cycle to 75 in the second cycle.

The increasing of student's activity supported by the increasing of teachers' activity in maintaining and enhancing the learning atmosphere that leads to Cooperative learning. It can be recognized from the observation of teacher activity increased from $80 \%$ to $89 \%$ in the second cycle. The enhancing student's activity in carrying out an evaluation of the ability to master the subject matter is appeared from the evaluation results.
It increased from 59 to 85 in the second cycle. The average of daily test raise from 65 at pree-cycle to 73 in the first cycle, 79 in the second cycle. Therefore, the researchers concluded that the study does not need to proceed to the third cycle

Based on the results in the first cycle, there are several things to note both positive and negative as investigation of implementation of this model. Some notes determining at the first cycle are as follow: From the observation shows that the first cycle is not successful. The average student progress is 45 . The students' average progress is still 75. Therefore it needs to be resolved by applying Cooperative model Mind Map Script Type into the learning process.

There was progress at the second meeting on the average 54. But it is not significant yet. The implemented model needs to be enhanced by rising the student and group members' motivation.

Student self-confident is increase at the third meeting. It's shown from student enthusiasm in reporting and presenting their group discussion. Student makes a colorful and interesting topic card as their enthusiasm of the lesson. It's drawn from second cycle progress bellow:

In the first meeting, students look more confident in expressing the idea and in communicating; they are motivated in doing 
LDS and material given. Students pay strong attention to the lesson $\mathrm{n}$ order to have good performance in presenting the finding.

The second cycle of this third meeting. Student learning motivation rise significantly, especially in group work. the learning of Islamic education meets the target, the class average is 74 . It shows that the students' learning affectivity is increased. Students show their enthusiasm in learning by presenting their well-prepared work group. Student support each member in order to be the best group presenting. The students are able to great atmosphere of team work.

This process results in enhancing of students' learning motivation and student enthusiasm to involve into group work, students express their idea confidently. Recapitulation conducted to evaluate learning process is very affective, student average progress rise from $29 \%$ to $85 \%$. Maximum completeness criteria rises from 65 to 79 .

\section{CONCLUSION AND RECOMMENDATION}

1. The students' progress and learning activity can be increased through the application of Cooperative Model mind map script type.

2. The observation showed the increasing of students' activity in the first and second cycle from $54 \%$ to $75 \%$.

3. Students' ability or group discussion is also significantly enhanced. Student are able to participate actively in discussion group.

4. Students' mastery is also increased. The daily test shows that pre-cycle progress 65 rises to 79 .

5. Students discipline, communication and group work ability are trained to be more affective.

In teaching and learning activities, teachers are expected to use cooperative model of (SM2) as an alternative to increase students' activity and learning progress. This research is also very useful, especially for teachers and students. It is expected that these activities can be apply in teaching Islam.

\section{REFERENCES}

Lie, A. (2007). Cooperative Learning. Jakarta : Grasindo.

Arikunto, S. (1998). Dasar-dasar Evaluasi Pendidikian . Jakarta : Bumi Aksara.

--- (2010). Penelitian Tindakan Kelas.Jakarta: Bumi Aksara

Dick and Carey (1985). The system design of instruction. Glenview:scott Foresman.

Dimyati \& Mujiono (2002). Belajar dan Pembelajaran. Jakarta : Rineka Cipta.

Jerold, K. (1995). Instructional Design.h.25. California ; Bermunt.

Kunandar. (2008). Guru Profesional. Jakarta : Raja Grafindo Persada.

--- (2010). Langkah Mudah Penelitian Tindakan Kelas. Jakarta: raja Grafindo.

Maryunis, A. (2003). Action Research dalam bidang Pendidikan.Vol

IV.skolar.Padang:Program

Pascasarjana UNP.

Silberman, M. (2002). Active Learning, 101 Strategy Pembelajaran Aktif. Yogyakarta: YAPPENDAIS

Syah, M. (1995). Psikologi Pendidikan Dengan Pendekatan Baru. Bandung : Rosda Karya.

Rusman. (2010). Model-model Pembelajaran. Jakarta : Rajawali Pers.

Sujana, N. ( 2001). Penilaian Hasil Belajar Mengajar. Bandung : Remaja Rosdakarya.

Djamarah, S. B. \& Zain, A. (1996). Strategi Belajar Mengajar. Jakarta : Rineka Cipta.

Tafsir, A. (2004) . Ilmu Pendidikan Perspektif Islam. Bandung: : Remaja Rosdakarya

Yoga, D. (2006). Buzan Mind Map. Jakarta:UPH. 